Ilchenko Hanna,

$\mathrm{PhD}$ (Law Sciences), Associate Professor, Kyiv National University of Trade and Economics, 19, Kyoto str., Kyiv, 02156, Ukraine ORCID: 0000-0003-1996-7062, Researcher ID: M2200-2016 Ilchenko Anton, $\mathrm{PhD}$ (Law Sciences), Sales director of Alfa-Garant Insurance Company, Kyiv, Ukraine ORCID: 0000-0001-7501-2979

\title{
THE IMPACT OF JUDICIAL PRACTICE ON INSURANCE RELATIONS
}

The judicial practice of the new Supreme Court is analyzed in relation to the justification by insurance companies of refusal of insurance compensation under compulsory civil liability insurance of land vehicle owners, and conclusions are made about the impact of this decision on insurance legal relations.

Keywords: insurance indemnity, civil liability, no-fault liability, cassation court decision, Supreme Court.

Ільченко Анна, Ільченко Антон. Вплив судової практики на страхові відносини.

Проаналізовано судову практику нового Верховного Суду щэодо обтрунтування страховими компаніями відмови у здійсненні страхового відшкодування за договорами обов'язкового страхування цивільно-правової відповідальності власників наземних транспортних засобів, та зроблено висновки щзодо впливу иього рімення на страхові правовідносини.

Ключові слова: страхове відшкодування, иивільна відповідальність, відповідальність без вини, рімення суду касаџійної інстанції, Верховний Суд.

Relevance of research topic. Since the creation of the new Supreme Court and its activities in December 2017, much attention has been drawn to attorneys, lawyers, scholars and the public in those decisions taken by the Courts of Cassation within the Supreme Court, and in particular the decisions of the Grand Chamber of the Supreme 
Court, which essentially form «Ukrainian precedents». The high expectations that society has placed on the work of the new Supreme Court are, first and foremost, not a scientific component, but a purely practical aspect. This is due to the fact that these decisions lay down or change the existing business practices, approaches to fulfilling obligations, both contractual and tort, the possibility of protecting the violated or unrecognized rights and interests of citizens, etc. Therefore, we consider it expedient to find out in specific examples what influence certain court decisions of a higher court have on the development of insurance legal relations in Ukraine and payment of insurance indemnity by insurers in particular. Given that the most common type of insurance in Ukraine is compulsory insurance of civil liability of owners of land vehicles, the majority of disputes arising in the field of insurance relations and resolved in the courts, are disputes concerning payment of insurance indemnity under these contracts.

Formulation of the problem. In the light of the above, it becomes necessary to find out when insurers are obliged to compensate for damage caused by a secured vehicle in the absence of the fault of the owner of the vehicle, taking into account recent Supreme Court practice.

Analysis of recent researches and publications. This study is based primarily on the Supreme Court's case-law on matters of insurance, which is published in the periodic digest of this court (Daydzhest sudovoi praktiki, 2019) and in the Unified State Register of Judgments. Also, the grounds for analyzing the legal force of the Supreme Court's rulings, as a court of cassation, are the works of D. Luspenik (Luspenik, 2018) and O. Kibenko (Kibenko, 2019). Various aspects of insurance activity, including the issue of insurance payments, were investigated in the works of Patsuria N., Voitsekhovskaya I., Golovachova A. (Patsuriya, Voytsehovska, 2017), Ilchenko H. (Ilchenko, 2017).

Presenting main material. According to Art. 3 of the Act of Ukraine «On Compulsory Insurance of Civil Liability of Land Vehicle Owners» of July 1, 2004 (hereinafter - the Act of Ukraine «On CICL») the purpose of compulsory insurance of civil liability is to provide compensation for damage caused to life, the health and / or property of victims as a result of an accident and the protection of property interests of policyholders (Zakon Ukrainy, 2004).

Considering that according to the Patrol Police Department, between January and April 2019, there were 47,445 road accidents in Ukraine (hereinafter - road accident), in which 822 people were killed and 7804 people were injured (Stastistika DTP, 2019), and civil liability issues is very relevant.

In the event of an accident due to the fault of the driver, whose liability is insured, the insurance company must pay the insurance indemnity within the insurance amount stipulated in the Act of Ukraine «On CICL». 
From February 2016 in accordance with the Order of the National Financial Services Commission «On Amendments to the Order of the Financial Services Commission of July 9, 2010 No. 566» On Some Issues of Compulsory Insurance of Civil Liability of Land Vehicle Owners «dated 29.12.2015 No. 3470 (Rozporyadzhennya Natskomfinposlug, 2019), insurance amounts for internal agreements on compulsory civil liability insurance are set at:

- for damage to life and health - 200,000 UAH. one victim, regardless of the number of victims;

- for the damage caused to the property of the victims - UAH 100,000. per victim, but not more than $500000 \mathrm{UAH}$. for one insurance event.

It should be emphasized that these insurance sums are planned to be gradually increased, and in the autumn of 2019, they will be 260 thousand UAH. and UAH 130 thousand respectively (Limityi otvetstvennosti po OSAGO, 2018; Rozporyadzhennya Natskomfinposlug, 2019).

Damage to the life and health of the victim as a result of a traffic accident, in accordance with Art. 23 of the Act of Ukraine «On CICL» is:

- damage related to the treatment of the victim;

- damage related to the temporary disability of the victim;

- damage related to the permanent loss of disability of the victim;

- moral damage arising from the physical pain and suffering suffered by the injured individual in connection with the injury or other damage to health;

- the damage associated with the death of the victim.

The victims in this case include:

- the driver and passengers of the car that has suffered;

- passengers who were in the culprit's car;

- persons who were in the care of the victim.

However, each type of damage listed above has its own peculiarities of calculation. So, despite the fact that the limit of the sum insured at the death of the victim is 200 thousand $\mathrm{UAH}$, that does not mean that the insurance company will pay all 200 thousand in case of death of a person, which is a direct consequence of an accident.

Article 27 of the Act of Ukraine «On CICL» provides that in connection with the death of the victim, the following shall be compensated: moral damages and costs for the burial and construction of the tombstone. Compensation for damages shall be made on equal terms in accordance with Article 1200 of the Civil Code of Ukraine (Tsivilniy kodeks Ukraiini, 2018) to each person entitled to such compensation. The total amount of insurance indemnity to the dependents of one deceased may not be less than the 36 minimum monthly wages established by law on the day of the insured event. According to Art. 8 of the Act of Ukraine «On the State Budget of Ukraine for 
2019» the minimum wage is January 1, 20194173 UAH (Zakon Ukrainy, 2018). That is, the amount of such insurance indemnity in 2019 may not exceed UAH 150,228.

The insurer also indemnifies the moral damage caused by the death of the individual, her husband (wife), parents (adoptive parents) and children (adopted children). The total amount of such insurance indemnity to these persons in respect of one deceased is 12 minimum monthly wages, set by law on the day of the occurrence of the insured event, and is paid in equal installments to the other surviving spouse, parents and children. That is, in 2019 this amount may not exceed UAH 50,076.

The costs of burial and erection of the tombstone are also offset by the actual costs, but not exceeding 12 minimum wages at the time of the insured event. That is, in this case in 2019 this amount also does not exceed 50076 UAH. Payment is made to the person who can document with the insurer that they have incurred these costs. It should be noted that the funeral dinner in this case is not compensated by the insurance company.

Thus, the total amount of insurance compensation in connection with the death of the victim may be less than 200 thousand UAH.

However, there are cases where the accident does not result from the fault of the driver provided with the vehicle. According to patrol police statistics (Stastistika DTP, 2019), it can be: the fault of children under 18; the fault of the drivers of motor vehicles related causes of committing technical malfunctions of the vehicle; road accident with the victims of the fault of the owners of the road network; accidents with victims, caused by pedestrians' fault (drunkenness; crossing in an unspecified place); accidents with victims, committed in case of unsatisfactory condition of roads or streets, etc.

In this case, the driver is not guilty, but since the vehicle is classified by law as a source of increased danger, the person who owns, uses, stores or holds the vehicle is liable for the damage if it does not prove that the damage was caused by force majeure or intent of the victim (Article 1187 of the Civil Code of Ukraine (Tsivilniy kodeks Ukraiini, 2018).

According to Art. 32 of the Act of Ukraine «On CICL» (Zakon Ukrainy, 2014), among other cases where the damage is not compensated, the first paragraph fixes the damage caused during the operation of the secured vehicle, but which does not give rise to civil liability in accordance with the law (paragraph 32.1).

As case law shows, insurers often resort to this point, justifying their refusal to pay insurance. A striking example of the unequal interpretation and application of the rules by the courts in this case is the case, which was heard in three instances and was already finalized in the decision of Civil Cassation Court within the Supreme Court of 23 January 2019 (Postanova Kasatsiynogo tsivilnogo sudu, 2019). In this case, in refusing to satisfy the claim, the court of first instance concluded that the defendant 
(insurance company) had no civil liability under the law, since criminal proceedings against the driver of the insured vehicle were closed in the absence of a crime in his actions.

Further, in reversing the decision of the court of first instance and adopting a new one on the satisfaction of the claim, the court of appeal, concluded that the civil liability of the PERSON_2 driver at the time of the accident was insured by insurance company «Alfa-Garant», therefore, taking into account the requirements of Article 1187 Civil Code of Ukraine, Article 6 of the Act of Ukraine «On CICL», the defendant is obliged to compensate the plaintiff for the damage.

However, when the decision of court of appeal was quashed and the decision of court of first instance upheld by the court of cassation, it stated that under Article 22 of the Act of Ukraine «On CICL» the insurer indemnifies in accordance with the limits of liability of the insurer in accordance with the procedure established by this law the estimated damage, which was caused as a result of a traffic accident to the life, health, property of a third party. The defendant did not incur civil liability in accordance with paragraph 32.1 of Article 32 of the Act of Ukraine «On CICL».

It follows from the foregoing that the trial court and the cassation instance applied paragraph 32.1 of Art. 32 of the Act of Ukraine «On CICL» in favor of an insurance company. However, given the unequal application by the courts of substantive law in similar legal relationships referred to by the plaintiff and the analysis set out in the ruling of 23 January 2019, the Supreme Court came to the following conclusion: «The obligation to indemnify property damage caused by a source of increased danger arises under the following conditions: presence of damage; wrongful conduct of the person causing the damage; the existence of a causal link between the unlawful behavior of the person causing the harm and its result - the harm» (Postanova Kasatsiynogo tsivilnogo sudu, 2019).

Conclusion. From the above it follows that the reference to paragraph 32.1 of Art. 32 of the Act of Ukraine «On CICL» in court will not be grounds for the release of the insurer from payment of insurance indemnity, since the presence of guilt is not a prerequisite for this. Thus, even if the driver's fault in the accident is absent, the insurance company still has to compensate for the damage caused by the insured vehicle.

The aforementioned decision of the Civil Cassation Court within the Supreme Court set a precedent, since it is no use now for insurers to invoke paragraph 32.1. Art. 32 of the Act of Ukraine «On CICL» to justify its refusal of insurance indemnity. When appealing such a refusal in court, the courts must use the practice of the Supreme Court, and the instructions contained in the decision of cassation court, in accordance with Art. 417 of the Civil Procedure Code of Ukraine are binding on the court of first and appellate court during the new trial of the case. However, as 
D. Luspenik rightly points out: «The power of the judgments of the Supreme Court should be manifested not in the obligation for lower courts, but in the reasoning, persuasiveness, compliance with the requirements of the rule of law, and hence their high authority for lower courts» (Luspenik D., 2018).

The existence of such court practice certainly protects the interests of victims, but at the same time deprives insurance companies of the ability to rely on a rule of law to justify their refusal. And given that insurance companies are not charitable organizations, depriving them of their right to a justified refusal to make insurance payments under a special law will certainly have a negative economic effect for insurers.

\section{REFERENCES}

1. Daydzhest sudovoi praktiki Verhovnogo Sudu u spravah, pov'yazanih zi strahovimi pravovidnosinami. Kyiv, 2019. 38 p. Retrieved from https://supreme. court.gov.ua/userfiles/media/Dajdjest.pdf [in Ukrainian].

2. Ilchenko, H.O. (2017). Zahist prav spozhivachiv strahovih poslug: monografiya. Kiiv : Kiiiv. nats. torg.-ekon. un-t, 184 p. [in Ukrainian].

3. Kibenko, O. (2019). Koli rishennya Verhovnogo Sudu nabirae chinnosti: problemni pitannya na prikladi GPK Ukraini. Yuridichna gazeta online. Retrieved from http://yur-gazeta.com/publications/practice/gospodarske-pravo/koli-rishennya-vcnabirae-chinnosti-problemni-pitannya-na-prikladi-gpk-ukrayini.html [in Ukrainian].

4. Limityi otvetstvennosti po OSAGO v Ukraine budut uvelichenyi v 2019 godu na 30\%, s 2020 v 5 raz, s 2025 v 80 raz. (2018) https:/forinsurer.com/ news/19/01/29/36543 [in Ukrainian].

5. Luspenik, D. (2018). Zavdannya Verhovnogo Sudu yak sudu kasatsiynoi instantsii. Sudovo-yuridichna gazeta, 28 grudnya 2018. Retrieved from https://sud.ua/ru/news/blog/131533-zavdannya-verkhovnogo-sudu-yak-sudukasatsiynoyi-instantsiyi-0f98bd. [in Ukrainian].

6. Patsuriya, N. B., Voytsehovska, I. M., Golovachova, A. S. (2017). Pravove regulyuvannya diyalnosti u sferi strahuvannya ta perestrahuvannya: problemi teorii ta praktiki: monografiya; Kiiv. nats. un-t im. Tarasa Shevchenka. Kiiv : Lira-K, 254 p. [in Ukrainian].

7. Politsiya opublikuvala zhahlivu statistiku DTP: golovna prichina perevischennya shvidkosti. (2019). Retrieved from https://www.unian.ua/economics/ transport/10541229-policiya-opublikuvala-zhahlivu-statistiku-dtp-golovna-prichinaperevishchennya-shvidkosti.html [in Ukrainian]. 
8. Postanova Kasatsiynogo tsivilnogo sudu u skladi Verhovnogo Sudu vid 23 sichnya 2019 roku m. Kiiv sprava № 674/1666/14-ts. Retrieved from http://reyestr.court.gov.ua/Review/79472450. [in Ukrainian].

9. Rozporyadzhennya Natsionalnoi komisii, scho zdiysnyue derzhavne regulyuvannya u sferi rinkiv finansovih poslug «Pro vnesennya zmin do rozporyadzhennya Derzhfinposlug vid 09.07.2010 №566 «Pro deyaki pitannya zdiysnennya obov'yazkovogo strahuvannya tsivilno-pravovoi vidpovdalnosti vlasnikiv nazemnih transportnih zasobiv» vid 29.12.2015 № 3470 (n.d.) zakon.rada.gov.ua. Retrieved from http://zakon3.rada.gov.ua/laws/show/z0145-16 [in Ukrainian].

10. Rozporyadzhennya Natskomfinposlug vid 09.04.2019 № 538 «Pro vnesennya zmin do deyakih normativno-pravovih aktiv z pitan obov'yazkovogo strahuvannya tsivilno-pravovoi vidpovidalnosti vlasnikiv nazemnih transportnih zasobiv» (n.d.) zakon.rada.gov.ua. Retrieved from http://search.ligazakon.ua/ 1_doc2.nsf/link1/RE33515.html [in Ukrainian].

11. Tsivilniy kodeks Ukraiini: chinne zakonodavstvo zi zminami ta dopovnennyami stanom na 18 chervnya 2018 roku. K. PALIVODA A.V., 2018. 448 p. [in Ukrainian].

12. Zakon Ukrainy «Pro Derzhavniy byudzhet Ukraini na 2019 rik» vid 23.11.2018 [Law of Ukraine «On the State Budget of Ukraine for 2019» of 23.11.2018]. (n.d.) zakon.rada.gov.ua. Retrieved from https://zakon.rada.gov.ua/laws/ show/2629-19. [in Ukrainian].

13. Zakon Ukrainy «Pro obov'yazkove strahuvannya tsivilno-pravovoi vidpovidalnosti vlasnikiv nazemnih transportnih zasobiv» vid 01.07.2004 № 1961-IV [Law of Ukraine «On compulsory insurance of civil liability of owners of land vehicles»] (n.d.) zakon.rada.gov.ua. Retrieved from https://zakon.rada.gov.ua/laws/ show/1961-15[in Ukrainian]. 